\title{
Article \\ The Effect of Sn Addition on Zn-Al-Mg Alloy; Part I: Microstructure and Phase Composition
}

\author{
Peter Gogola * (D), Zuzana Gabalcová (D), Martin Kusý (D) and Henrich Suchánek \\ Institute of Materials Science, Faculty of Materials Science and Technology in Trnava, Slovak University of \\ Technology in Bratislava, Ulica Jána Bottu 25, 91724 Trnava, Slovakia; zuzana.gabalcova@stuba.sk (Z.G.); \\ martin.kusy@stuba.sk (M.K.); henrich.suchanek@stuba.sk (H.S.) \\ * Correspondence: peter.gogola@stuba.sk
}

Citation: Gogola, P.; Gabalcová, Z.; Kusý, M.; Suchánek, H. The Effect of Sn Addition on Zn-Al-Mg Alloy; Part I: Microstructure and Phase Composition. Materials 2021, 14, 5404. https://doi.org/10.3390/ma14185404

Academic Editor: Jana Bidulská

Received: 27 July 2021

Accepted: 14 September 2021

Published: 18 September 2021

Publisher's Note: MDPI stays neutral with regard to jurisdictional claims in published maps and institutional affiliations.

Copyright: (c) 2021 by the authors. Licensee MDPI, Basel, Switzerland. This article is an open access article distributed under the terms and conditions of the Creative Commons Attribution (CC BY) license (https:/ / creativecommons.org/licenses/by/ $4.0 /)$.

\begin{abstract}
In this study, the addition of Sn on the microstructure of $\mathrm{Zn} 1.6 \mathrm{wt} \% \mathrm{Al} 1.6 \mathrm{wt} . \% \mathrm{Mg}$ alloy was studied. Currently, the addition of Sn into $\mathrm{Zn}-\mathrm{Al}-\mathrm{Mg}$ based systems has not been investigated in detail. Both as-cast and annealed states were investigated. Phase transformation temperatures and phase composition was investigated via DSC, SEM and XRD techniques. The main phases identified in the studied alloys were $\eta(\mathrm{Zn})$ and $\alpha(\mathrm{Al})$ solid solutions as well as $\mathrm{Mg}_{2} \mathrm{Zn}_{11}, \mathrm{MgZn}_{2}$ and $\mathrm{Mg}_{2} \mathrm{Sn}$ intermetallic phases. Addition of $\mathrm{Sn}$ enabled the formation of $\mathrm{Mg}_{2} \mathrm{Sn}$ phase at the expense of $\mathrm{Mg}_{\mathrm{x}} \mathrm{Zn}_{\mathrm{y}}$ phases, while the overall volume content of intermetallic phases is decreasing. Annealing did not change the phase composition in a significant way, but higher Sn content allowed more effective spheroidization and agglomeration of individual phase particles.
\end{abstract}

Keywords: Zn-based alloy; phase composition; XRD; DSC; microstructure formation; Sn-addition; intermetallic phases

\section{Introduction}

$\mathrm{Zn}-\mathrm{Al}$ alloys are used as corrosion protection coatings for a series of applications including steel strands used to reinforce overhead power lines. Such strands ensure the overall mechanical rigidity of aluminum conductors and thus reduce the number of supporting towers needed for a specific distance of overhead power lines [1]. These power lines are designed to operate at about $180^{\circ} \mathrm{C}$, while due to an increased current load, they may heat up to $300{ }^{\circ} \mathrm{C}$. [1,2] Pure Zn coatings are not suitable in such conditions. Above $200{ }^{\circ} \mathrm{C}$, the pure $\mathrm{Zn}$ coating starts to react with the steel $[1,3,4]$ substrate and continues to form $\mathrm{ZnFe}$ intermetallics. Such a reaction can reduce the actual steels cross section area and thus reduce the cables' mechanical properties. This limitation can be overcome by alloying $[5,6]$.

Nowadays, various Zn-Al-Mg alloy system coatings are available, such as the commercially well-known Magizinc (MZ) with a chemical composition of Zn $1.6 \mathrm{wt}$ \% Al 1.6 wt.\% Mg [7-14].

$\mathrm{Mg}$ is added to $\mathrm{Zn}$-based coatings to further increase their corrosion protection capabilities. $\mathrm{Mg}$ is useful especially for increasing the galvanic protection offered by a coating at cut-edges and mechanically damaged spots. Additional alloying may further improve the properties of Zn-Al-Mg alloys as reported by several literature sources [15-25]. Unfortunately, there is still lack of information about Sn addition into these systems [26].

In recent years, the effects of $\mathrm{Sn}$ addition on the microstructure of $\mathrm{Mg}$ - and Al-based alloys has been studied. This includes microstructural stability upon thermal exposure. Sn is known to have a high affinity to $\mathrm{Mg}$, creating mainly the $\mathrm{Mg}_{2} \mathrm{Sn}$ intermetallic phase. All in all, a positive influence of $\mathrm{Sn}$ on $\mathrm{Mg}$ and Al-based alloys has been reported depending on the amount of $\mathrm{Sn}$ added to these alloys. Alloying enabled the formation of $\mathrm{Mg}_{2} \mathrm{Sn}$ in all these alloys [27-33]. The aim of this research is to confirm if $\mathrm{Mg}_{2} \mathrm{Sn}$ phase is also preferred compared to $\mathrm{Mg}_{\mathrm{x}} \mathrm{Zn}_{\mathrm{y}}$ phases in the current alloy system as suggested by studied 
literature sources $[32,34]$. Phase composition and overall microstructure character will be investigated on as-cast samples.

As one of the potential applications involves a long-term thermal exposure, microstructure and phase composition will be investigated after a representative annealing treatment of each alloy as well. Experimental annealing temperature will be set to $310{ }^{\circ} \mathrm{C}$ to be clearly above potential exposure temperatures, but below the melting temperatures $\left(\sim 340^{\circ} \mathrm{C}\right)$ of the investigated alloys.

$\mathrm{Mg}_{2} \mathrm{Zn}_{11}$ and $\mathrm{MgZn} \mathrm{n}_{2}$ are the most common intermetallic phases in the currently investigated $\mathrm{Zn}$-based systems. $\mathrm{MgZn}_{2}$ is reported to be less ductile, while both are reported to be slightly less ductile compared to $\mathrm{Mg}_{2} \mathrm{Sn}[18-20,29,35,36]$. The possibility to replace $\mathrm{Mg}_{\mathrm{x}} \mathrm{Zn}_{\mathrm{y}}$ phases by $\mathrm{Mg}_{2} \mathrm{Sn}$ and thus reduce the overall volume content of intermetallic phases in a $\mathrm{Zn} 1.6 \mathrm{wt} . \% \mathrm{Al} 1.6 \mathrm{wt} \% \mathrm{Mg}$ based alloy would indicate an interesting research path for further extensive investigation of corrosion and mechanical properties of such alloys.

\section{Materials and Methods}

Five different alloys with the designed nominal composition of $\mathrm{Zn}-1.6 \mathrm{Al}-1.6 \mathrm{Mg}-\mathrm{xSn}$ (wt.\%), where $x=0.0,0.5,1.0,2.0$ and $3.0 \mathrm{wt} \%$, respectively, were prepared by melting pure $\mathrm{Zn}$ at $470{ }^{\circ} \mathrm{C}$ and mixing in the appropriate amount of a $50 \mathrm{wt} \% \mathrm{Al}$ and $50 \mathrm{wt} . \% \mathrm{Mg}$ master alloy. These raw materials were preheated to $400{ }^{\circ} \mathrm{C}$ to facilitate their rapid melting. Due to the low melting point of Sn, it was added in the last step. Table 1 indicates that the measured bulk chemical compositions of the alloys by glow discharge optical emission spectroscopy (GDOES, Spectruma GDA 750, Spectruma Analytik GmbH, Hof, Germany) are in good agreement with the nominal ones.

Table 1. Chemical composition of the studied alloys (wt.\%).

\begin{tabular}{ccccc}
\hline Alloy & Al & Mg & Sn & Zn \\
\hline$M Z+0.0 S n$ & $1.56 \pm 0.07$ & $1.40 \pm 0.01$ & $0.07 \pm 0.02$ & bal. \\
$M Z+0.5 S n$ & $1.64 \pm 0.02$ & $1.41 \pm 0.01$ & $0.52 \pm 0.01$ & bal. \\
$M Z+1.0 S n$ & $1.62 \pm 0.03$ & $1.45 \pm 0.02$ & $1.06 \pm 0.02$ & bal. \\
$M Z+2.0 S n$ & $1.57 \pm 0.01$ & $1.44 \pm 0.01$ & $1.95 \pm 0.01$ & bal. \\
$M Z+3.0 S n$ & $1.57 \pm 0.12$ & $1.43 \pm 0.05$ & $2.69 \pm 0.06$ & bal. \\
\hline
\end{tabular}

Casting was done from $470{ }^{\circ} \mathrm{C}$ of melt temperature into a water-cooled copper mold with a diameter of $30 \mathrm{~mm}$ and depth of $20 \mathrm{~mm}$. During casting, the sample temperature was continuously measured at a sampling frequency of $25 \mathrm{~Hz}$ with K-type thermocouples attached to the mold surface. The cooling rate of $60^{\circ} \mathrm{C} / \mathrm{s}$ was established.

Two types of cylindrical samples were prepared for each alloy: (i) as-cast samples and (ii) cast and subsequently solution annealed at $310^{\circ} \mathrm{C}$ for $1 \mathrm{~h}$. The annealing step was finished by ice-water quenching. A cooling rate of $75^{\circ} \mathrm{C} / \mathrm{s}$ was recorded. The selected solution annealing temperature corresponds to the $\gamma+\eta$ region of the Zn-Al system [37], while it is clearly below the melting point of all chosen alloys. Cooling in cold water ensured a very good control of the annealing time.

Vickers hardness tests were carried out in line with ISO 6507-1 [38] on polished surfaces of as-cast and annealed samples via a BUEHLER Indentamet 1105 (Buehler Ltd., Lake Bluff, IL, USA) hardness tester at an applied load of $9.8 \mathrm{~N}$, holding time at the point of load application was $10 \mathrm{~s}$.

DSC measurements were carried out by the Perkin Elmer Diamond DSC (Perkin Elmer Inc., Billerica, MA, USA) device. The DSC samples were cut from as-cast samples to a target weight of $5 \mathrm{mg}$. The samples were heated to the temperature of $500{ }^{\circ} \mathrm{C}$ at a heating rate of $10^{\circ} \mathrm{C} / \mathrm{min}$ and then cooled to ambient temperature at a cooling rate of $10{ }^{\circ} \mathrm{C} / \mathrm{min}$ under the protective argon atmosphere.

The XRD analysis was carried out on metallic filings of the as-cast and annealed samples by the PANalytical Empyrean X-ray diffractometer (XRD) (Malvern Panalytical 
Ltd., Malvern, UK). The procedure to measure on metallic filings instead of bulk castings was chosen to limit the influence of casting texture on the recorded XRD pattern. The casting texture added additional complexity to the XRD measurements by influencing the theoretical relative intensities for the individual crystallographic planes. This made the quantitative analysis very unreliable due to the complex texture corrections needed. The measurements were performed in Bragg-Brentano geometry. Theta-2Theta angle range between $10^{\circ}$ and $148^{\circ} 2$ Theta was chosen. The XRD source was set to $40 \mathrm{kV}$ and $40 \mathrm{~mA}$. The incident beam was modified by $0.04 \mathrm{rad}$ soller slit, $1 / 4^{\circ}$ divergence slit and $1 / 2^{\circ}$ anti-scatter slit. The diffracted beam path was equipped with a $1 / 2^{\circ}$ anti-scatter slit, 0.04 rad soller slit, $\mathrm{Ni}$ beta filter and PIXcel3D position sensitive detector operated in 1D scanning mode. The phase quality was analyzed using PANalytical Xpert High Score program (HighScore Plus version 3.0.5) with the ICSD FIZ Karlsruhe database. Quantitative results were determined from XRD patterns using the Rietveld refinement-based program MAUD version 2.84 [39]. The program uses an asymmetric pseudo-Voight function to describe experimental peaks. Instrument broadening was determined by measuring the NIST660c LaB 6 (The National Institute of Standards and Technology, Gaithersburg, MD, USA) line position and line broadening standard and introduced to the Rietveld refinement program via the Caglioti equation. Anisotropy size-strain model was applied to $\mathrm{Zn}$ solid solution while other phases were treated by isotropic models. A minor discrepancy between the nominal and measured peak intensities was corrected using the spherical harmonic functions with fibre symmetry. The quality of the fit was in all analyzed samples below $10 \% \mathrm{R}_{\mathrm{wp}}$.

The metallographic preparation of DSC, as-cast and annealed samples consisted of standard grinding using abrasive papers and polishing on diamond pastes with various grain sizes of down to $0.25 \mu \mathrm{m}$.

The microstructure evaluation was performed by the JEOL JSM 7600F scanning electron microscopy (SEM, Jeol Ltd., Tokyo, Japan) with a Schottky field emission electron source operating at $20 \mathrm{kV}$ and $90 \mu \mathrm{A}$. The samples were placed at a working distance of $15 \mathrm{~mm}$ and documented using a backscattered electron detector. The chemical element analysis was performed via the Oxford Instruments X-Max silicon drift detector, energy dispersive X-ray spectrometer (EDS, Oxford Instruments plc, Abingdon, UK).

Image analysis was performed on at least 15 sites for each sample by ImageJ FIJI $1.53 \mathrm{c}$ software [40]. Area ratio of $\eta(\mathrm{Zn})$ based areas and other microstructure components were established.

All results are listed as the average values of multiple measurements with \pm standard deviation error bars.

\section{Results}

The DSC curves of MZ + xSn alloys system in Figure 1a-e show charts of DSC heating runs. Figure 1 shows the most relevant section of the recorded data, while measurements were done from 20 to $500{ }^{\circ} \mathrm{C}$ at a heating rate of $10^{\circ} \mathrm{C} / \mathrm{min}$. The first heating runs recorded are presented to observe the reactions in the as-cast samples during heating and subsequent melting, including eutectoid reactions (not visible in DSC cooling runs). 


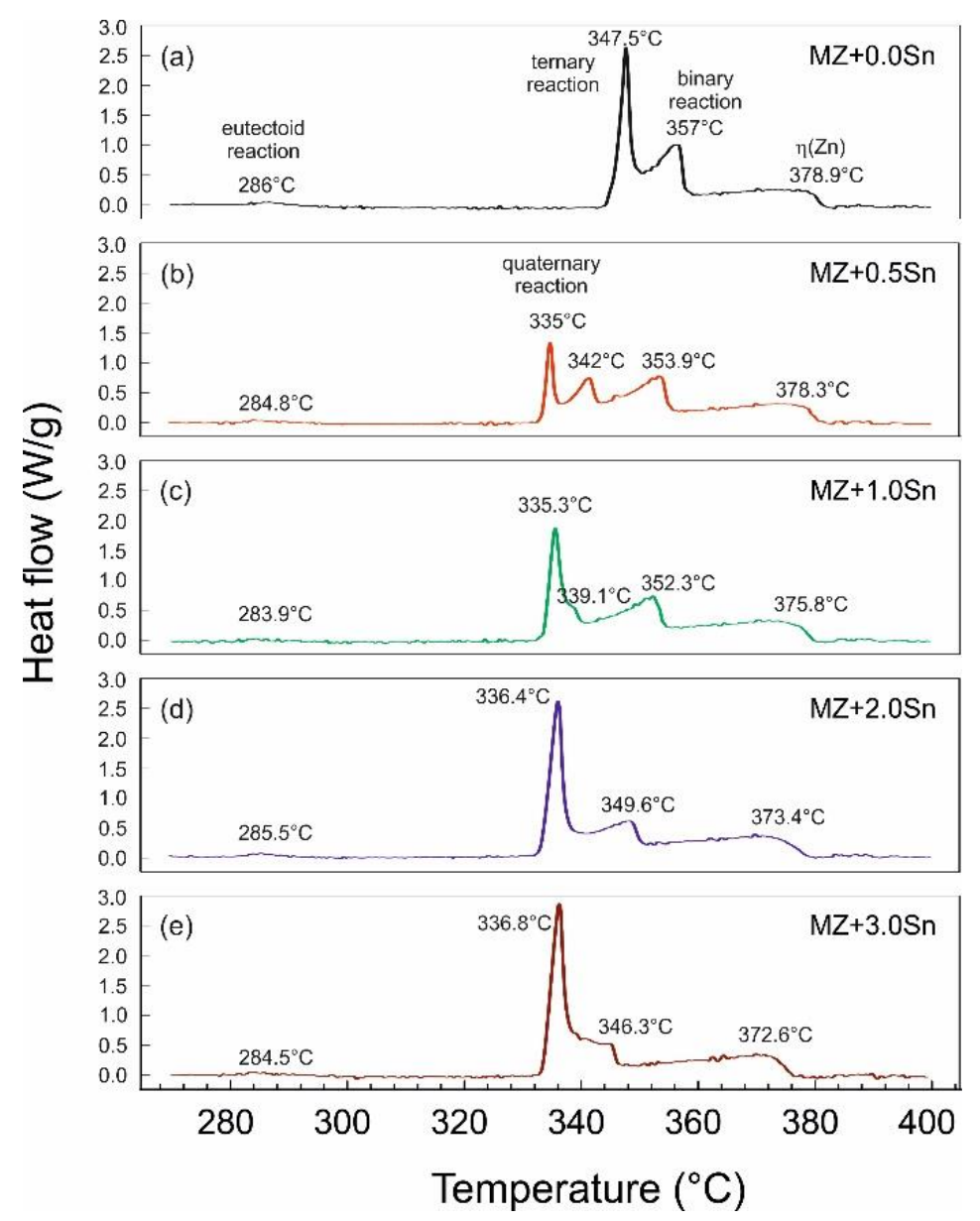

Figure 1. Comparison of the DSC curves for all investigated alloys.

Hence, the individual microstructure features in the as-cast samples cannot be clearly distinguished; the DSC samples after the cooling run were investigated via SEM. These observations enabled us to identify the individual reactions for each recorded peak.

Peaks were recorded describe the reactions of the following phases: $\eta(\mathrm{Zn})-\mathrm{hcp} \mathrm{Zn}$ based solid solution; $\gamma(\mathrm{Al})-\mathrm{fcc} \mathrm{Al}$-based solid solution present above the eutectoid reaction temperature reported at $275^{\circ} \mathrm{C}$ in the $\mathrm{Zn}$ - $\mathrm{Al}$ system [37] up to melting temperature; $\alpha(\mathrm{Al})$ fcc Al-based solid solution present below the $\mathrm{Zn}$ - $\mathrm{Al}$ system eutectoid reaction; $\mathrm{Mg}_{2} \mathrm{Zn}_{11}$, $\mathrm{MgZn}_{2}$ and $\mathrm{Mg}_{2} \mathrm{Sn}$ intermetallic phases of respective systems.

The curve in Figure 1 a corresponds to the $\mathrm{MZ}+0.0 \mathrm{Sn}$ alloy. The first peak observed at about $285.0^{\circ} \mathrm{C}$ corresponds to the eutectoid transformation $\alpha(\mathrm{Al})+\eta(\mathrm{Zn}) \rightarrow \gamma(\mathrm{Al})$. This peak is repeated for all alloys observed. Melting of pure $\mathrm{MZ}+0.0 \mathrm{Sn}$ starts at $344.0^{\circ} \mathrm{C}$ (peak maximum at $347.5^{\circ} \mathrm{C}$ ) with melting of the ternary eutectic consisting of $\eta(\mathrm{Zn}), \gamma(\mathrm{Al})$ and $\mathrm{Mg}_{2} \mathrm{Zn}_{11}$ phases. An example of such areas is provided in Figure 2a. This is followed by the melting of the $\mathrm{Zn} / \mathrm{Mg}_{\mathrm{x}} \mathrm{Zn}_{\mathrm{y}}$ binary eutectic (peak maximum at $357.0^{\circ} \mathrm{C}$ ). A clear example can be observed in Figure $2 \mathrm{~b}$. $\mathrm{Mg}_{\mathrm{x}} \mathrm{Zn}_{\mathrm{y}}$ corresponds to a mixture of $\mathrm{Mg}_{2} \mathrm{Zn}_{11}$ and $\mathrm{MgZn}_{2}$ phases as documented in Figure 2c. A closer detail of this area is given in Figure 2d) showing also the $\alpha(\mathrm{Al})+\eta(\mathrm{Zn})$ eutectoid particles in detail. Chemical composition of the individual phases is documented in Table 2. The last peak corresponds with the melting of the $\mathrm{Zn}$ rich dendrites (peak maximum at $378.9^{\circ} \mathrm{C}$ ) [41]. 

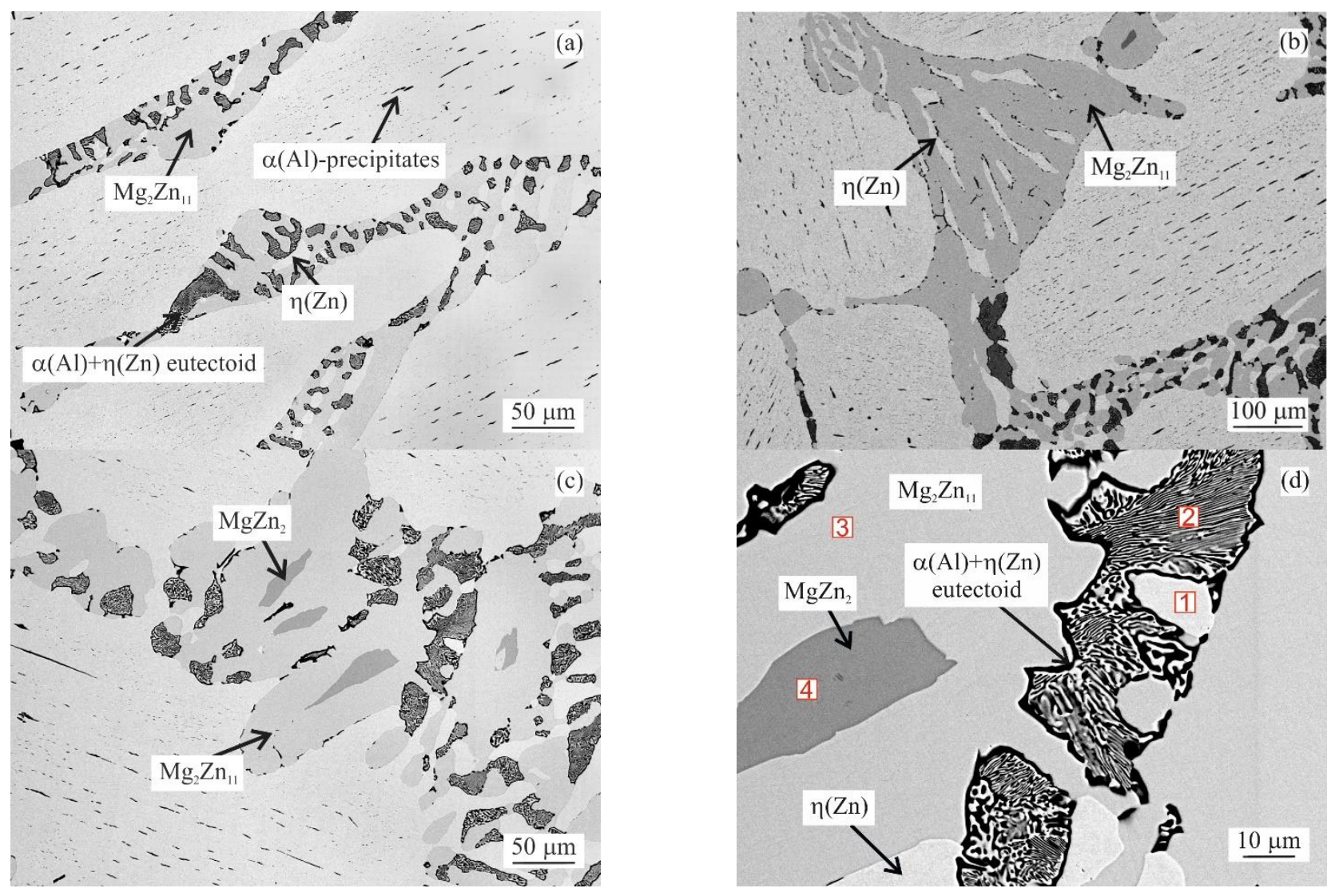

Figure 2. Selected features of $M Z+0.0 S n$ alloy microstructure after DSC measurement: (a) example of ternary eutectic; (b) example of binary eutectic; (c) example of $\mathrm{Mg}_{2} \mathrm{Zn}_{11}$ and $\mathrm{MgZn} \mathrm{n}_{2}$ mixture; (d) area with EDS measurement points 1-4 listed in Table 2.

Table 2. EDS chemical composition of selected sites (at.\%).

\begin{tabular}{ccccccc}
\hline & \multicolumn{7}{c}{ Site No. } \\
\hline Chemical Element (at.\%) & $\mathbf{1}$ & $\mathbf{2}$ & $\mathbf{3}$ & $\mathbf{4}$ & $\mathbf{5}$ \\
\hline $\mathrm{Zn}$ & 99.20 & 54.50 & 83.70 & 66.30 & 66.10 \\
$\mathrm{Al}$ & 0.80 & 45.50 & - & - & - \\
$\mathrm{Mg}$ & - & - & 16.30 & 33.70 & - \\
$\mathrm{Sn}$ & - & - & - & - & 33.90 \\
Phase/Region & $\eta(\mathrm{Zn})$ & $\alpha(\mathrm{Al})+\eta(\mathrm{Zn})$ eutectoid & $\mathrm{Mg}_{2} \mathrm{Zn}_{11}$ & $\mathrm{MgZn}_{2}$ & $\mathrm{Mg}_{2} \mathrm{Sn}$ \\
\hline
\end{tabular}

As indicated in Figure $2 a, \eta(Z n)$ dendrites are always decorated by a needle like $\alpha(\mathrm{Al})$ particles. These are formed as a result of the decreasing solubility of $\mathrm{Al}$ in $\mathrm{Zn}$ in the temperature range below $\sim 285^{\circ} \mathrm{C}$ (see Figure 1). These particles are observed for all alloys investigated.

As observed in Figure 1b, the addition of $0.5 \mathrm{wt} . \%$ of Sn enables the formation of a peak at $335^{\circ} \mathrm{C}$. This effect corresponds to newly emerging quaternary eutectic areas consisting of $\eta(\mathrm{Zn}), \gamma(\mathrm{Al}), \mathrm{Mg}_{2} \mathrm{Zn}_{11}$ and $\mathrm{Mg}_{2} \mathrm{Sn}$ phases. A typical such area is shown in Figure $3 \mathrm{a}$ ) with a selected detail in Figure 3b. The chemical composition of the $\mathrm{Mg}_{2} \mathrm{Sn}$ phase was measured and listed in Table 2. These areas start to melt at about $334{ }^{\circ} \mathrm{C}$ (peak maximum at $\left.335.0^{\circ} \mathrm{C}\right)$. The next peak corresponds to the melting of the ternary eutectic $\left(342.0^{\circ} \mathrm{C}\right)$ composed of $\eta(\mathrm{Zn}), \gamma(\mathrm{Al})$ and $\mathrm{Mg}_{2} \mathrm{Zn}_{11}$. The adjacent peak indicates the melting of the $\eta(\mathrm{Zn})+\mathrm{Mg}_{2} \mathrm{Zn}_{11}$ binary eutectic $\left(353.9^{\circ} \mathrm{C}\right)$. The peak at $378.3^{\circ} \mathrm{C}$ indicates the melting of the remaining $\eta(\mathrm{Zn})$ dendrites. 

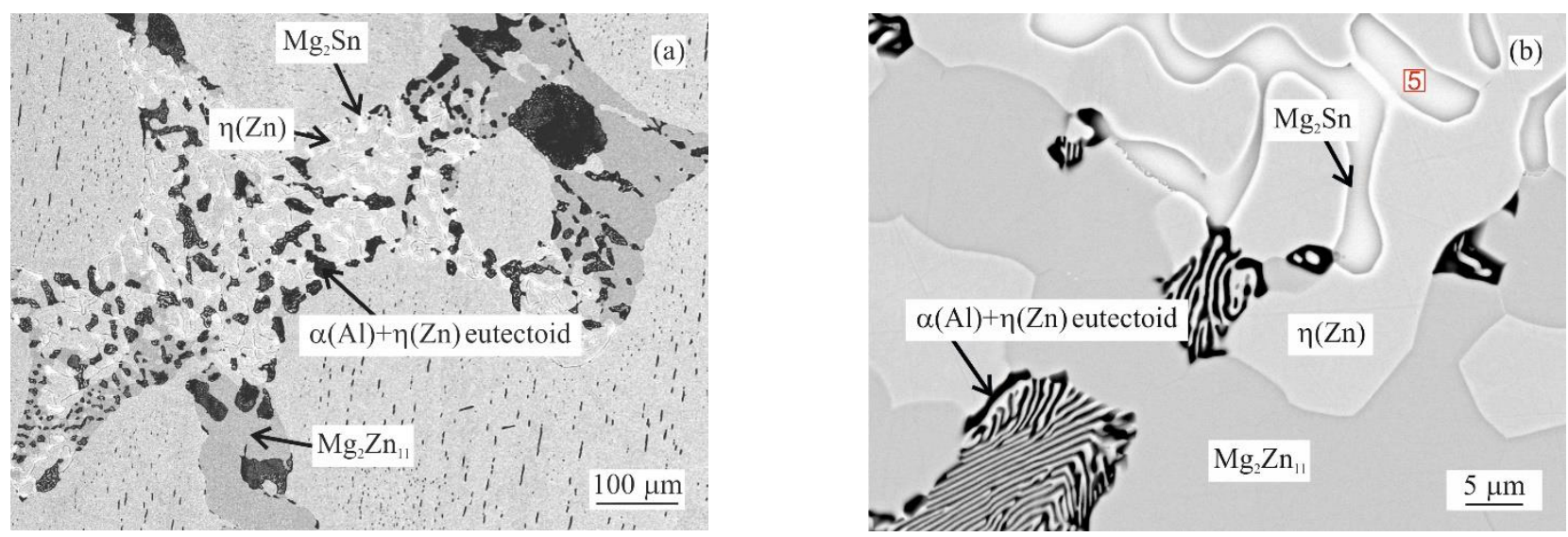

Figure 3. Quaternary eutectic area in $\mathrm{MZ}+0.5 \mathrm{Sn}$ alloy microstructure after DSC measurement: (a) example of quaternary eutectic; (b) closer detail of such area including EDS measurement point 5 listed in Table 2.

The alloy with $1 \mathrm{wt} . \%$ of Sn (Figure 1c) has a minor peak left corresponding to the ternary eutectic $\left(339.1^{\circ} \mathrm{C}\right)$, while the peak corresponding to the quaternary eutectic $\left(335.3^{\circ} \mathrm{C}\right)$ increased further in peak area. Both other peaks correspond to the same reactions as described above.

With $2 \mathrm{wt} . \%$ of Sn (Figure 1d), the melting starts at $333.5^{\circ} \mathrm{C}$. This reaction melts the complex eutectic area shown in Figure 4 . The peak corresponding to the ternary eutectic reaction is not resolved separately anymore. The peak at $349.6{ }^{\circ} \mathrm{C}$ in this alloy represents the melting of two binary eutectics: $\eta(\mathrm{Zn})+\mathrm{Mg}_{2} \mathrm{Zn}_{11}$ as well as $\eta(\mathrm{Zn})+\mathrm{Mg}_{2} \mathrm{Sn}$. The last peak in this DSC curve at $373.4{ }^{\circ} \mathrm{C}$ corresponds again to $\eta(\mathrm{Zn})$ dendrites.

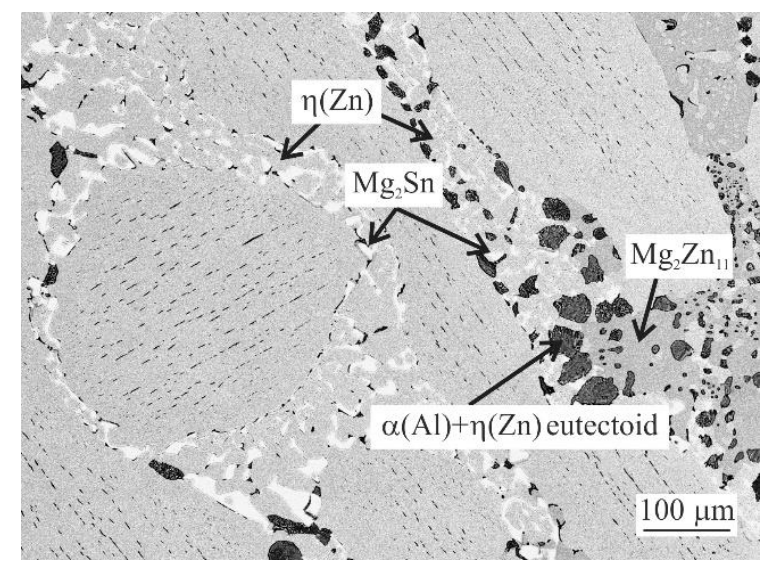

Figure 4. Binary and quaternary eutectic areas in MZ + 2.0Sn alloy microstructure after DSC measurement.

Adding $3 \mathrm{wt} . \%$ of Sn (Figure 1e) changes the peak of the quaternary eutectic reaction only slightly (peak maximum at $336.8^{\circ} \mathrm{C}$ ). The peak observed at $346.3{ }^{\circ} \mathrm{C}$ corresponds according to microstructure observations solely to the melting of the binary $\eta(\mathrm{Zn})+\mathrm{Mg}_{2} \mathrm{Sn}$ eutectic. Melting of the remaining $(\eta) \mathrm{Zn}$ is indicated by the peak at $372.6^{\circ} \mathrm{C}$.

XRD measurements were performed on the metallic filings prepared from the bulk samples. Figures 5 and 6 shows the XRD patterns for selected alloys in the as-cast and annealed state, respectively. A quantitative analysis using the Rietveld method was performed considering the phases listed in Table 3 characterized in the ICSD FIZ Karlsruhe database. These phases enabled the identification of all significant peaks in the measured XRD patterns. 


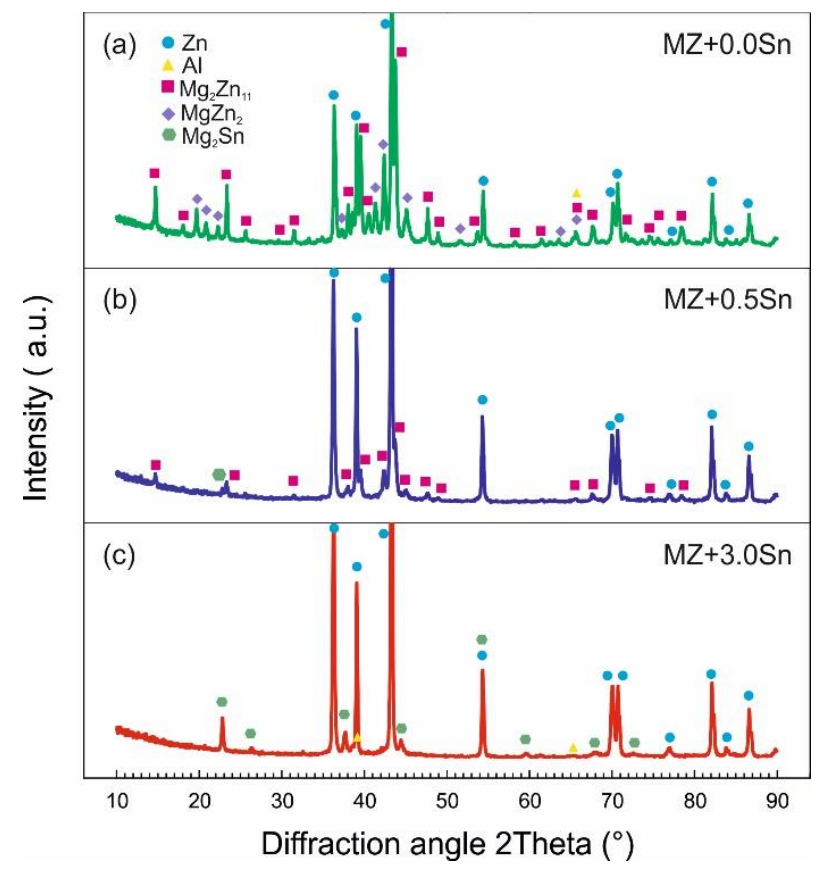

Figure 5. XRD diffraction patterns recorded on powder samples of selected alloys in as-cast state (a) $\mathrm{MZ}+0.0 \mathrm{Sn},(\mathbf{b}) \mathrm{MZ}+0.5 \mathrm{Sn},(\mathbf{c}) \mathrm{MZ}+3.0 \mathrm{Sn}$.

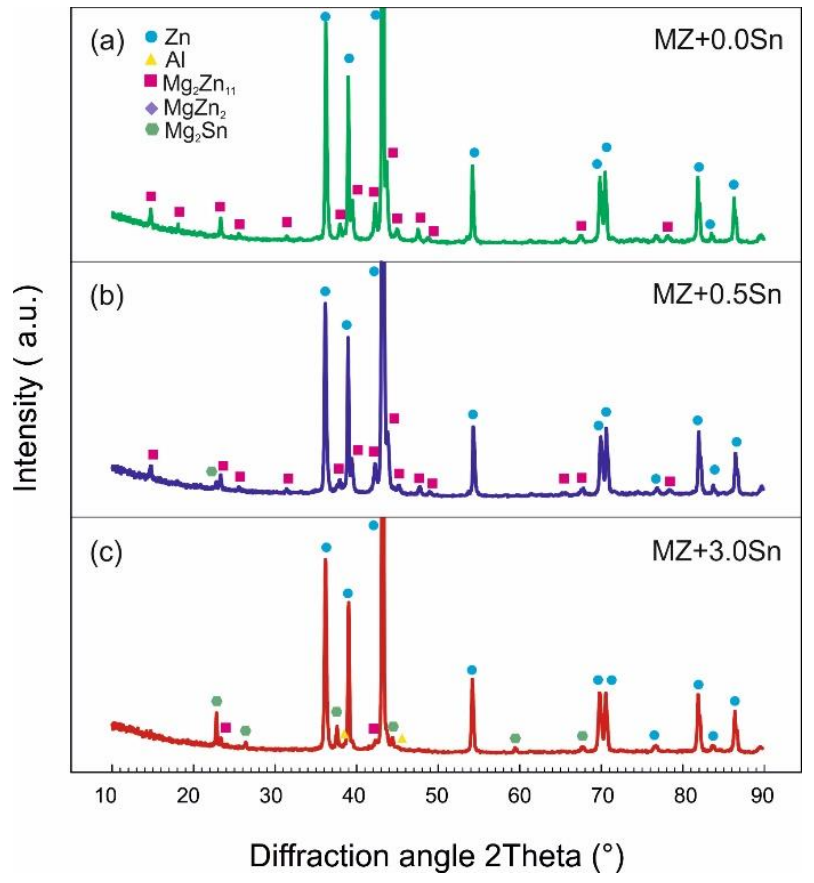

Figure 6. XRD diffraction patterns recorded on powder samples of selected alloys in annealed state (a) $\mathrm{MZ}+0.0 \mathrm{Sn},(\mathbf{b}) \mathrm{MZ}+0.5 \mathrm{Sn},(\mathbf{c}) \mathrm{MZ}+3.0 \mathrm{Sn}$. 
Table 3. Phases identified during XRD analysis.

\begin{tabular}{ccccc}
\hline $\begin{array}{c}\text { Phase Chemical } \\
\text { Formula }\end{array}$ & $\begin{array}{c}\text { Reference Code-ICSD } \\
\text { Database FIZ Karlsruhe }\end{array}$ & Crystal System & Space Group & Space Group Number \\
\hline$\eta(\mathrm{Zn})=\mathrm{Zn}+2$ at.\% Al & $\begin{array}{c}98-024-7160 \\
\text { modified according [42] }\end{array}$ & Hexagonal & $P 6_{3} / m m c$ & 194 \\
$\alpha(\mathrm{Al})=\mathrm{Al}+14$ at.\% $\mathrm{Zn}$ & $98-060-6001$ & Cubic & $F m \overline{3} m$ & 225 \\
$\mathrm{MgZn} 2$ & modified according [42] & Hexagonal & $P 6_{3} / m m c$ & 194 \\
$\mathrm{Mg}_{2} \mathrm{Zn}_{11}$ & $98-010-4897$ & Cubic & $P m \overline{3}$ & 200 \\
$\mathrm{Mg}_{2} \mathrm{Sn}$ & $98-064-2855$ & Cubic & $F m \overline{3}$ & 225 \\
\hline
\end{tabular}

As the cooling speed in all experiments was rather high at $60-75^{\circ} \mathrm{C} / \mathrm{s}$ for both as-cast and annealed samples, it was assumed that the solubility changes below the eutectoid transformation $\left[\gamma(\mathrm{Al}) \rightarrow \alpha \mathrm{Al}+\eta(\mathrm{Zn})\right.$ at $\left.275^{\circ} \mathrm{C}\right]$ will be significantly limited. Such a phenomenon was reported for $\alpha(\mathrm{Al})$ as well as $\eta(\mathrm{Zn})$ phases by Gogola et al. [42] based on XRD measurements of $\mathrm{Zn}-\mathrm{Al}$ based samples. To enable the correct quantitative analysis of $\alpha(\mathrm{Al})$ as well as $\eta(\mathrm{Zn})$ phases, their chemical composition had to be changed by adding 14 at.\% of $\mathrm{Zn}$ and 2 at.\% of $\mathrm{Al}$, respectively, as suggested in this publication. The chemical composition of the phases was changed in MAUD software before the quantitative analysis of each XRD pattern. The soundness of this approach was double checked comparing the GDOES chemical composition data with the chemical composition calculated from XRD quantitative analysis for each sample.

The volume content of individual phases in the as-cast samples evolved as shown in Figure 7.

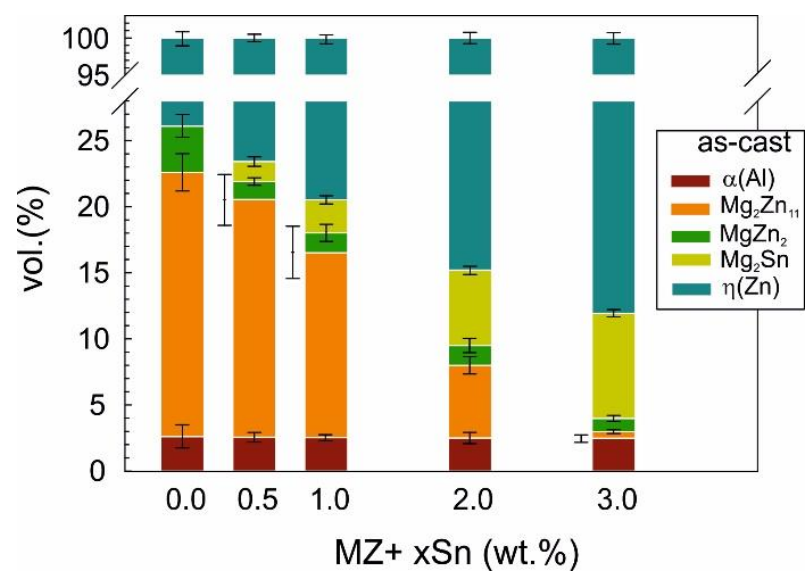

Figure 7. Phase composition in vol.\% in metallic bulk samples as measured on metallic filings from as-cast samples.

In all alloys, both $\mathrm{Mg}_{2} \mathrm{Zn}_{11}$ as well as the non-equilibrium $\mathrm{MgZn}_{2}$, the intermetallic phases can be detected. The overall content of $\mathrm{Mg}_{\mathrm{x}} \mathrm{Zn}_{\mathrm{y}}$ intermetallic phases was reduced from 23.5 vol. $\%$ to about 1.5 vol. \% by adding $3 \mathrm{wt} . \%$ of Sn into the basic $\mathrm{Zn} 1.6 \mathrm{wt} . \% \mathrm{Al}$ 1.6 wt. $\% \mathrm{Mg}$ (MZ) alloy. At the same time, the $\mathrm{Mg}_{2} \mathrm{Sn}$ phase occupied about 8 vol. $\%$ of the as-cast $\mathrm{MZ}+3.0 \mathrm{Sn}$ alloy.

The content of $\mathrm{MgZn}_{2}$ was reduced from 3.5 vol. $\%$ to 1.5 vol. $\%$ by adding $0.5 \mathrm{wt} . \%$ of $\mathrm{Sn}$. The further addition of Sn did not change the content of this phase significantly. Its content was gradually further reduced to 1 vol. $\%$ by adding up to $3 \mathrm{wt} . \%$ of $S n$ into the alloy. However, at $\sim 1$ vol. $\%$ of $\mathrm{MgZn}_{2}$, the detectability limit of $\mathrm{MgZn}_{2}$ was likely reached in the current alloy with the applied measurement setup.

$\mathrm{Mg}_{2} \mathrm{Zn}_{11}$ phase was detected in all alloys. Its content was gradually reduced from $\sim 20$ vol. $\%$ down to below 1 vol. $\%$ by adding up to $3 \mathrm{wt} . \%$ of $S n$. 
Peaks corresponding to $\mathrm{Mg}_{2} \mathrm{Sn}$ can be already clearly identified in the as-cast $\mathrm{MZ}+0.5 \mathrm{Sn}$ sample representing as low as $1.5 \mathrm{vol} . \%$ of this phase. Its volume content clearly gradually increased up to $\sim 8$ vol. $\%$ when $3 \mathrm{wt}$. \% of Sn was added.

The content of $\alpha(\mathrm{Al})$ is calculated to be 2.5 vol. $\%$ on average across all alloys investigated. Addition of $\mathrm{Sn}$ did not change the content of $\alpha(\mathrm{Al})$ in a significant way.

Annealing the investigated alloys clearly influenced their phase composition (Figure 8) as calculated from XRD measurements (Figure 6).

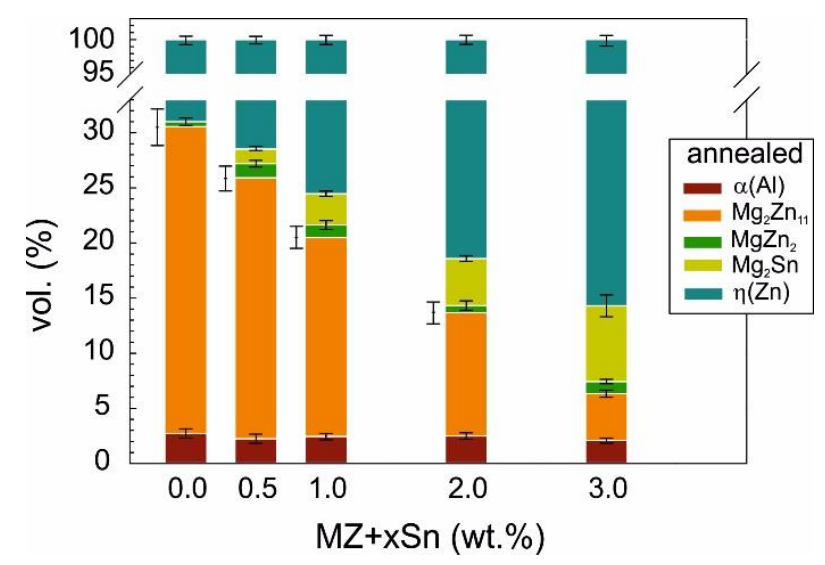

Figure 8. Phase fractions in vol.\% in metallic bulk samples as measured on metallic filings of annealed samples.

In the $\mathrm{MZ}+0.0 \mathrm{Sn}$ alloy, the content of non-equilibrium $\mathrm{MgZn} \mathrm{n}_{2}$ is significantly reduced after annealing. Its content is reduced from $\sim 3.5$ vol. $\%$ to below 1 vol. $\%$. For all the other alloys, the content of $\mathrm{MgZn}_{2}$ is rather similar in both as-cast and annealed states.

The content of the $\mathrm{Mg}_{2} \mathrm{Zn}_{11}$ phase increases to 28 vol. \% after annealing the $\mathrm{MZ}+0.0 \mathrm{Sn}$ alloy, hence indicating that this is the equilibrium phase for this alloy [34,37]. Additionally, for all the other compositions, the volume content of $\mathrm{Mg}_{2} \mathrm{Zn}_{11}$ increases after annealing. Annealing changes the content of $\mathrm{Mg}_{2} \mathrm{Sn}$ only slightly. Most noticeably, its content reduces at 2 and 3 wt. $\%$ of $\mathrm{Sn}$, probably in favor of $\mathrm{Mg}_{2} \mathrm{Zn}_{11}$. The content of $\alpha(\mathrm{Al})$ remains basically unchanged by the annealing process.

Comparison of microstructure images for the most important edge cases is given in Figure $9 a-f$. Figure $9 a, c, e$ correspond to as-cast states, while Figure $9 b, d, f$ correspond to the annealed state.

The microstructure of $\mathrm{MZ}+0.0 \mathrm{Sn}$ samples is formed by $\eta(\mathrm{Zn})$ phase dendrites, where the interdendritic areas are formed by a mixture of binary $\eta(\mathrm{Zn}) / \mathrm{Mg}_{\mathrm{x}} \mathrm{Zn}_{\mathrm{y}}$ eutectic and ternary $\eta(\mathrm{Zn}) / \alpha(\mathrm{Al}) / \mathrm{Mg}_{\mathrm{x}} \mathrm{Zn}_{\mathrm{y}}$ eutectic $[43,44]$. Adding $0.5 \mathrm{wt}$.\% of $\mathrm{Sn}$ changes the microstructure appearance in an insignificant way (Figure 9a vs. Figure 9c). On the other hand, in Figure $9 e$, we can clearly observe the presence of $\eta(\mathrm{Zn}) / \mathrm{Mg}_{2} \mathrm{Sn}$ binary eutectic regions. Gradual addition of $\mathrm{Sn}$ reduces the amount of $(\eta) \mathrm{Zn} / \mathrm{Mg}_{\mathrm{x}} \mathrm{Zn}_{\mathrm{y}}$ eutectic regions and gives rise to $\eta(\mathrm{Zn}) / \mathrm{Mg}_{2} \mathrm{Sn}$ eutectic regions. Additionally, areas formed by $\eta(\mathrm{Zn}) / \alpha(\mathrm{Al}) / \mathrm{Mg}_{\mathrm{x}} \mathrm{Zn}_{\mathrm{y}}$ ternary eutectic are reduced in favor of probably $\eta(\mathrm{Zn}) / \alpha(\mathrm{Al}) / \mathrm{Mg}_{\mathrm{x}} \mathrm{Zn}_{\mathrm{y}} / \mathrm{Mg}_{2} \mathrm{Sn}$ quaternary eutectics.

Figure $9 b, d, f$ shows the microstructure of selected alloys after annealing. $\eta(\mathrm{Zn})$ loses its dendritic character as well as all interdendritic areas being spheroidized, while areas with common chemical compositions are connected. None of the previously described eutectic regions can be recognized. Based on XRD, the vast majority of $\mathrm{Mg}_{\mathrm{x}} \mathrm{Zn}_{\mathrm{y}}$ particles are corresponding to $\mathrm{Mg}_{2} \mathrm{Zn}_{11}$. As annealing was done above the eutectoid temperature of the $\mathrm{Zn}$-Al system $\left(285^{\circ} \mathrm{C}\right.$ as reported by DSC measurements, Figure 1$)$, Al rich particles were spheroidized as $\gamma(\mathrm{Al})$ particles. Hence, the outer shape of Al rich particles remained frozen while decomposition to $\alpha(\mathrm{Al})+\eta(\mathrm{Zn})$ eutectoid particles took place upon cooling from annealing temperature. 

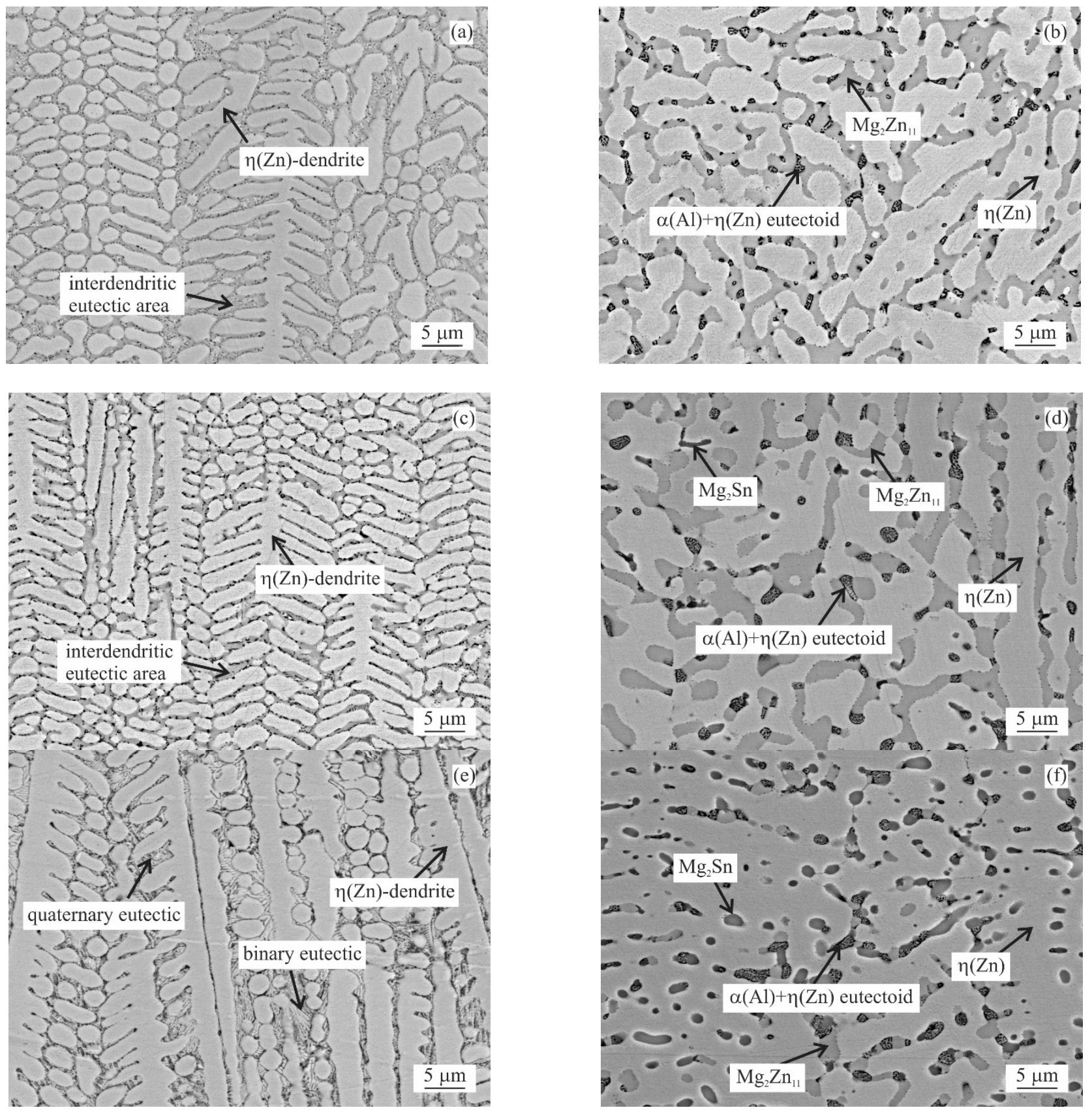

Figure 9. Microstructure images for selected samples, longitudinal section, near sample surface: (a) MZ + 0.0Sn as-cast, (b) $\mathrm{MZ}+0.0 \mathrm{Sn}$ annealed, (c) MZ + 0.5Sn as-cast, (d) MZ + 0.5Sn annealed, (e) MZ + 3.0Sn as-cast, (f) MZ + 3.0Sn annealed.

Figure 10 summarizes the vol.\% of all other microstructure components apart from $\eta(\mathrm{Zn})$.

For as-cast samples, this represents the interdendritic spaces which are formed mainly by various eutectics including a certain portion of $\eta(Z n)$ phase solidified within them as well as $\alpha(\mathrm{Al})+\eta(\mathrm{Zn})$ eutectoid particles.

For the annealed samples, it was possible to clearly distinguish between $\eta(\mathrm{Zn})$ matrix and all intermetallic phase particles along with $\alpha(\mathrm{Al})+\eta(\mathrm{Zn})$ eutectoid particles.

The difference between data for as-cast and annealed samples is mainly caused by the fact that $\eta(\mathrm{Zn})$ solidified in the interdendritic spaces of the as-cast samples cannot be separately identified, while during annealing, these small $\eta(\mathrm{Zn})$ particles are allowed to connect to the larger primary $\eta(\mathrm{Zn})$ areas forming a uniform matrix. 


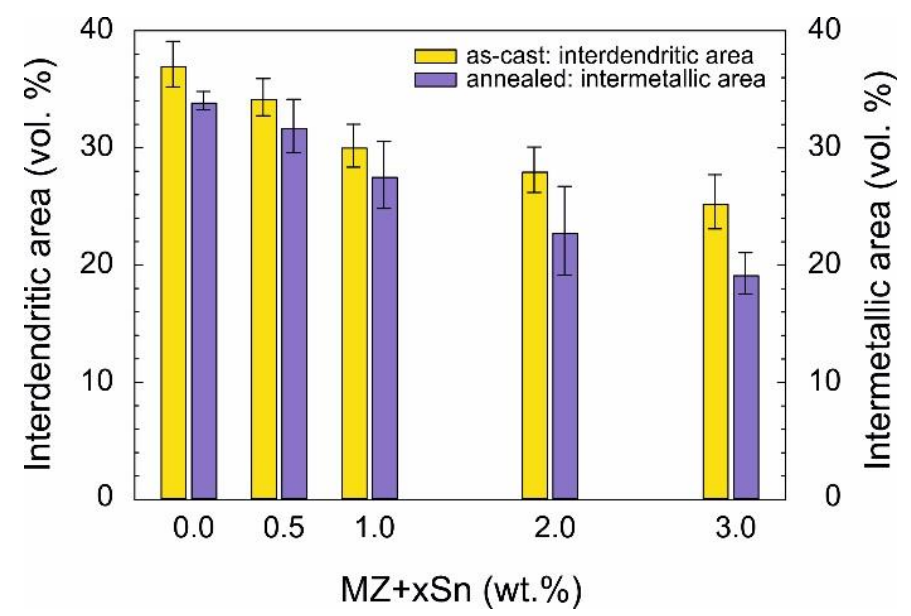

Figure 10. Vol.\% of microstructural components as determined from SEM image analysis.

In general, the vol.\% of all other microstructure components outside of $\eta(\mathrm{Zn})$ is decreasing with the addition of $\mathrm{Sn}$ into the investigated alloys.

Microhardness was measured on the as-cast and the corresponding annealed samples as well. All samples showed an over twice higher hardness compared to pure $\mathrm{Zn}$. $\mathrm{MZ}+0.0 \mathrm{Sn}$ showed the hardness of $\sim 113 \mathrm{HV}$, while the gradual addition of Sn was almost linearly decreasing the alloy's hardness down to $\sim 85 \mathrm{HV}$ measured on the MZ $+3.0 \mathrm{Sn}$ as-cast sample. Annealing of these samples further decreased their hardness, however, by only 3 to $7 \%$ compared to respective as-cast states of each alloy.

\section{Discussion}

Sn was chosen to supplement the composition of ZnAlMg based alloys. Similar Znbased alloy compositions have not been reported in the literature so far, probably due to the concerns related to the corrosion properties of such alloys. These properties will be investigated in adjacent research.

Different aspects of the alloy's microstructure were investigated. The main phases identified were in the general agreement with the published data as follows: $\eta(\mathrm{Zn}), \alpha(\mathrm{Al})$, $\mathrm{Mg}_{2} \mathrm{Zn}_{11}, \mathrm{MgZn}_{2}[7-18,20-24]$ and $\mathrm{Mg}_{2} \mathrm{Sn}[26,27,32,33]$.

DSC curves can be clearly described only by investigating the microstructure of DSC samples after cooling in the DSC equipment (Figures 2-4). Copper mold as-cast microstructure is an order of magnitude finer and hence less likely to be clearly identified. A clear comparison can be for example given by comparing the size $\mathrm{Mg}_{2} \mathrm{Sn} / \eta(\mathrm{Zn})$ eutectic particles in Figure 4 (DSC sample of MZ + 3.0Sn) and Figure 9e (as-cast sample of MZ + 3.0Sn). Furthermore, the kinetic of solidification may also affect the order in which the phase or phase mixtures are formed. DSC curves show that the ternary $\eta(\mathrm{Zn}) / \alpha(\mathrm{Al}) / \mathrm{Mg}_{\mathrm{x}} \mathrm{Zn}_{\mathrm{y}}$ eutectics of $\mathrm{MZ}+0.0 \mathrm{Sn}$ alloy are replaced by quaternary $\eta(\mathrm{Zn}) / \alpha(\mathrm{Al}) / \mathrm{Mg}_{\mathrm{x}} \mathrm{Zn}_{\mathrm{y}} / \mathrm{Mg}_{2} \mathrm{Sn}$ eutectics by adding $1 \mathrm{wt}$.\% of $\mathrm{Sn}$. By gradually adding $\mathrm{Sn}$ from 0.0 to $1.0 \mathrm{wt}$.\%, the peak of the quaternary eutectic areas is formed at $\sim 335{ }^{\circ} \mathrm{C}$, while the peak of the ternary eutectic areas, found at temperatures in the range from 347.5 to $339.1^{\circ} \mathrm{C}$, is being gradually suppressed. Further addition of Sn (2.0 and $3.0 \mathrm{wt} . \%)$ causes the ternary reaction peak to shift towards even lower temperatures and being completely overlapped by the quaternary reaction peak. This is in line with available assessment of liquidus projection for the $\mathrm{Zn}-\mathrm{Mg}-\mathrm{Sn}$ ternary system [32,45]. These systems also predict a decrease in liquidus temperature for less complex eutectics when Sn concentration is approaching a more complex eutectic point near the Zn-rich corner of this system.

Peaks at $357-346.3{ }^{\circ} \mathrm{C}$ represent the binary eutectics. While DSC curves suggest only a gradual peak shift of binary eutectic reaction, the microstructure investigation showed that $\mathrm{Mg}_{2} \mathrm{Zn}_{11} / \eta(\mathrm{Zn})$ binary eutectics is being replaced by $\mathrm{Mg}_{2} \mathrm{Sn} / \eta(\mathrm{Zn})$ in case of the MZ + 3.0Sn alloy. Based on available ternary Zn-Mg-Sn assessments [32,45], it is 
hypothesized, that $\mathrm{Sn}$ supports the preferential formation of $\mathrm{Mg}_{2} \mathrm{Sn} / \eta(\mathrm{Zn})$ binary eutectic instead of $\mathrm{Mg}_{2} \mathrm{Zn}_{11} / \mathrm{\eta}(\mathrm{Zn})$ eutectic mixture. This is observed in the currently investigated system as well, despite the presence of $\mathrm{Al}$ as an additional alloying element. It is also worth mentioning that the temperature difference between the binary and ternary eutectic points calculated $[32,45]$ is only $1{ }^{\circ} \mathrm{C}$. This may cause difficulties to reveal the real order of solidification reactions since even a slight local chemical difference or temperature heterogeneity may cause local fluctuation and a competitive formation of $\mathrm{Mg}_{2} \mathrm{Sn} / \eta(\mathrm{Zn})$ and $\mathrm{Mg}_{2} \mathrm{Zn}_{11} / \eta(\mathrm{Zn})$ binary eutectic areas as indicated for the $\mathrm{MZ}+2.0 \mathrm{Sn}$ alloy.

Heating curves shown in Figure 1 depicted also the peaks corresponding to the $\alpha(\mathrm{Al})+\eta(\mathrm{Zn}) \rightarrow \gamma(\mathrm{Al})$ eutectoid transformation at $\sim 285^{\circ} \mathrm{C}$. The corresponding reaction cannot be observed during a cooling DSC run since this eutectoid transformation is rather sluggish; therefore, it is without a detectable heat release. The microstructure investigation shows that the $\gamma(\mathrm{Al}) \rightarrow \alpha(\mathrm{Al})+\eta(\mathrm{Zn})$ reaction clearly occurs; however, probably over a much broader temperature range compared to the heating curves. This reaction might be finished even at an ambient temperature [46].

Adding Sn reduced the volume content of $\mathrm{Mg}_{\mathrm{x}} \mathrm{Zn}_{\mathrm{y}}$ intermetallic phases, and these were replaced by $\mathrm{Mg}_{2} \mathrm{Sn}$ particles. This behavior is in line with the literature findings on similar systems [27,32]. The addition of Sn mainly affects the volume content of $\mathrm{Mg}_{2} \mathrm{Zn}_{11}$ (Figure 7).

For similar $\mathrm{Zn}-\mathrm{Al}-\mathrm{Mg}$ alloys, the sources report the same two $\mathrm{Mg}_{\mathrm{x}} \mathrm{Zn}_{\mathrm{y}}$ phases to be present [21,22,25,47]. Vlot et al. [47] identified only $\mathrm{MgZn}_{2}$ in similar alloys, while other literature sources confirmed the presence of both phases mentioned [21,22,25]. In our samples, $\mathrm{Mg}_{2} \mathrm{Zn}_{11}$ is the primary phase; however, $\mathrm{MgZn} \mathrm{n}_{2}$ was also clearly identified by both XRD and even SEM/EDX. At 3.5 vol.\%, its content was highest in the as-cast $\mathrm{MZ}+0.0 \mathrm{Sn}$ sample. As $\mathrm{MgZn}_{2}$ is a non-equilibrium phase in the current system, its content is significantly reduced by annealing the basic $\mathrm{MZ}+0.0 \mathrm{Sn}$ alloy at $310^{\circ} \mathrm{C}$ for $1 \mathrm{~h}$.

$\mathrm{Mg}_{2} \mathrm{Zn}_{11}$ and $M g Z n_{2}$ are competing phases and their final ratio is complex to predict and control even in a simple Mg-Zn alloy as reported by several sources [23,24]. All in all, their presence will depend on several factors like exact alloy composition or cooling rate [48].

The amount and distribution of intermetallic particles appears to have a direct influence on the microhardness of the studied alloys. Overall volume content of intermetallic phases is decreasing with the increasing wt.\% of Sn as measured by XRD (Figures 7 and 8) as well as the SEM image analysis (Figure 10). This is reflected in the decreasing alloy hardness summarized in Figure 11.

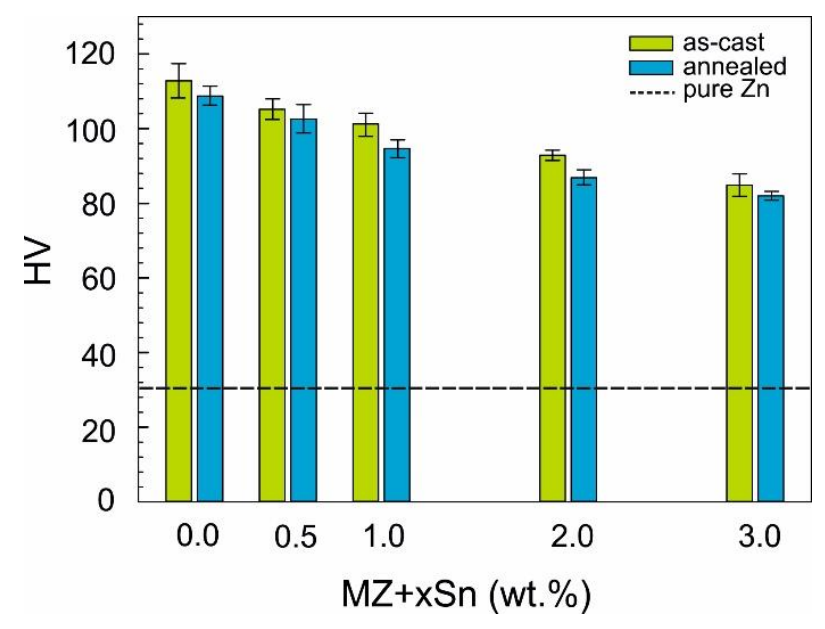

Figure 11. HV1 microhardness of the investigated samples.

Formation of $\mathrm{Mg}_{2} \mathrm{Sn}$ particles and the gradual increase of their vol.\% is reported to cause an increase in hardness for specific Mg-based alloys with similar Sn content [29-31]. 
The same mechanism does not apply to our Zn-based alloys, as in our samples, the overall vol. $\%$ of intermetallics is decreasing.

The hardness of as-cast samples is marginally higher compared to annealed samples (Figure 11). This is most probably caused mainly by the change in shape and distribution of the intermetallic particles. This can be observed when comparing the images of as-cast vs annealed conditions in Figure 9. The annealing allows $\eta(\mathrm{Zn})$ to diffuse from eutectics in the interdendritic areas towards the primary $\eta(\mathrm{Zn})$ dendrites, hence changing the eutectic nature of the interdendritic areas. For the $\mathrm{MZ}+0.0 \mathrm{Sn}$ and $\mathrm{MZ}+0.5 \mathrm{Sn}$ alloys, the original dendritic character of the microstructure can still be recognized even after annealing Figure 9 a vs. Figure $9 b, c$ vs. Figure $9 d$. For higher Sn content, this is not possible. The addition of 1 to $3 \mathrm{wt} . \%$ of $\mathrm{Sn}$ into this alloy system, enabled a more effective spheroidization and agglomeration of individual phase particles. Hence, the annealing had a more apparent influence on the microstructure of these alloys ( $\mathrm{MZ}+1.0 \mathrm{Sn}, \mathrm{MZ}+2.0 \mathrm{Sn}, \mathrm{MZ}+3.0 \mathrm{Sn}$ ).

For as-cast and annealed samples a different ratio of microstructural components was established for the same alloys by SEM. Nevertheless, both as-cast and annealed samples show the same trend compared to the XRD quantitative analysis. Additionally, for the annealed samples, the SEM image analysis and XRD analysis are in even better agreement.

\section{Conclusions}

Melting of MZ + 0.0Sn starts at $344^{\circ} \mathrm{C}$, while with the addition of $0.5-3.0 \mathrm{wt} . \%$ of Sn, melting starts already at $334{ }^{\circ} \mathrm{C}$. Melting is finished at $382{ }^{\circ} \mathrm{C}$ for the $\mathrm{MZ}+0.0 \mathrm{Sn}$ and this temperature is being continuously decreased to $376{ }^{\circ} \mathrm{C}$ by the addition of up to $3 \mathrm{wt} . \%$ of Sn.

Main phases identified in the MZ + 0.0Sn alloy were $\eta(\mathrm{Zn})$ and $\alpha(\mathrm{Al})$ solid solutions as well as $\mathrm{Mg}_{2} \mathrm{Zn}_{11}$ and $\mathrm{MgZn}$ intermetallic phases. Addition of $S n$ enabled the formation of $\mathrm{Mg}_{2} \mathrm{Sn}$ intermetallic phase at the expense of $\mathrm{Mg}_{\mathrm{x}} \mathrm{Zn}_{\mathrm{y}}$ phases, while mainly affecting the vol. $\%$ of $\mathrm{Mg}_{2} \mathrm{Zn}_{11}$.

The microstructure is dendritic for all as-cast alloys. The interdendritic areas are formed by the binary, ternary and quaternary eutectics specific for each alloy. Alloying with Sn causes the following changes of microstructural components: ternary eutectics consisting of $\eta(\mathrm{Zn}), \alpha(\mathrm{Al})$ and $\mathrm{Mg}_{\mathrm{x}} \mathrm{Zn}_{\mathrm{y}}$ phases are gradually replaced by quaternary $\eta(\mathrm{Zn})$, $\alpha(\mathrm{Al}), \mathrm{Mg}_{\mathrm{x}} \mathrm{Zn}_{\mathrm{y}}$ and $\mathrm{Mg}_{2} \mathrm{Sn}$ eutectics. Binary $\eta(\mathrm{Zn})+\mathrm{Mg}_{\mathrm{x}} \mathrm{Zn}_{\mathrm{y}}$ eutectics are gradually replaced by binary $\eta(\mathrm{Zn})+\mathrm{Mg}_{2} \mathrm{Sn}$ eutectics.

For the $\mathrm{MZ}+0.0 \mathrm{Sn}$ and $\mathrm{MZ}+0.5 \mathrm{Sn}$ alloys, the original dendritic character of the microstructure can still be recognized even after annealing. At the same time, the individual phases from the eutectics are connected to discrete particles, and thus the original eutectics are not recognizable anymore. Introducing 1 to $3 \mathrm{wt} . \%$ of Sn into this alloy system enabled a more effective spheroidization and agglomeration of individual phase particles significantly changing even the shape of the primary $\eta(\mathrm{Zn})$ dendrites.

Annealing causes slight changes in the phase composition. For MZ + 0.0Sn mainly $M g Z n_{2}$ is transformed to $\mathrm{Mg}_{2} Z_{11}$. For the alloys with $\mathrm{Sn}$, the volume content of $\mathrm{Mg}_{2} \mathrm{Zn}_{11}$ is partially increased mainly at the expense of $\mathrm{Mg}_{2} \mathrm{Sn}$.

The microhardness is decreasing with the increasing of Sn content. The annealing changes the microhardness only slightly.

Based on microstructure observation, these alloys are overall suitable for coatings exposed to extended high temperature exposure. As coatings of steel substrates, their corrosion properties will be at least maintained as reported in part two of this research: The effect of Sn addition on $\mathrm{Zn}-\mathrm{Al}-\mathrm{Mg}$ alloy-Part II.

Author Contributions: Conceptualization, P.G. and M.K.; methodology, P.G., Z.G. and M.K.; validation, P.G., Z.G., M.K. and H.S.; formal analysis, P.G., Z.G.; investigation, P.G., Z.G., M.K. and H.S.; resources, P.G., Z.G. and H.S.; data curation, P.G., Z.G. and M.K.; writing-original draft preparation, P.G. and Z.G.; writing—review and editing, P.G. and M.K.; visualization, P.G. and Z.G.; supervision, P.G. and Z.G.; project administration, P.G.; funding acquisition, M.K. All authors have read and agreed to the published version of the manuscript. 
Funding: This research was supported by the Grant Agency VEGA of the Slovak Ministry of Education, Research, Science and Sport, Project No. 1/0490/18: "The effect of microstructure and phase composition on corrosion resistance of hot dip alloys" and by the Slovak Research and Development Agency under the Contract no. APVV-20-0124.

Institutional Review Board Statement: Not applicable.

Informed Consent Statement: Not applicable.

Data Availability Statement: Data sharing is not applicable.

Conflicts of Interest: The authors declare no conflict of interest.

\section{References}

1. Coffin, C.; Depamelaere, H.; King, D.; Van Raemdonck, W. Evaluation of High Temperature Behavior of Zn and ZnAl Coatings on Core Wires and Strands for ACSR, ACSS and Alike Overhead Power Conductors, WJI 2010, Monterrey ITC Preview. pp. 68-75. Available online: https:/ / issuu.com/wirejournal/docs/de-aug10-reduced (accessed on 24 February 2021).

2. Kiessling, F.; Nefzger, P.; Nolasco, J.F.; Kaintzyk, U. Overhead Power Lines—Planning, Design, Construction, 1st ed.; Springer: Berlin/Heidelberg, Germany, 2003; p. 250. [CrossRef]

3. Mingyuan, G.U.; Notis, M.R.; Marder, A.R. The Effect of Continuous Heating on the Phase Transformations in Zinc-Iron Electrodeposited Coatings. Metall. Trans. A 1991, 22, 1737-1743. [CrossRef]

4. Onishi, M.; Wakamatsu, Y.; Miura, H. Formation and Growth Kinetics of Intermediate Phases in Fe-Zn Diffusion Couples. Trans. JIM 1974, 15, 331-337. [CrossRef]

5. Rico, Y.; Carrasquero, E.J. Microstructural Evaluation of Double-Dip Galvanized Coatings on Carbon Steel. MRS Adv. 2017, 2, 3917-3923. [CrossRef]

6. Wright, R.N. Wire coatings. In Wire Technology_Process Engineering and Metallurgy, 2nd ed.; Elsevier-Butterworth Heinemann Books: Oxforfd, UK, 2011; pp. 245-256, ISBN 9780128026786.

7. Tanaka, S.; Honda, K.; Takahashi, A.; Morimoto, Y.; Kurosaki, M.; Shindo, H.; Nishimura, K.; Sugiyama, M. The performance of a Zn-Al-Mg-Si hot-dip galvanized steel sheet. In Proceedings of the 5th International Conference on Zinc and Zinc Alloy Coated Steel Sheet (GALVATECH 2001), Brussels, Belgium, 26-28 June 2001; Lamberights, M., Ed.; Verl. Stahleisen: Düsseldorf, Germany, 2001; p. 153, ISBN 3-514-00673-3.

8. Morimoto, Y.; Honda, K.; Nishimura, K.; Tanaka, S.; Takahashi, A.; Shindo, H.; Kurosaki, M. Excellent Corrosion-resistant Zn-Al-Mg-Si Alloy Hot-dip Galvanized Steel Sheet "SUPER DYMA". Nippon Steel Tech. Rep. 2003, 87, $24-26$.

9. Nishimura, K.; Kato, K.; Shindo, H. Highly Corrosion-resistant Zn-Mg Alloy Galvanized Steel Sheet for Building Construction Materials. Nippon. Steel Tech. Rep. 2000, 81, 85-88. [CrossRef]

10. Shindo, H.; Nishimura, K.; Okado, T.; Nishimura, N.; Asai, K. Developments and Properties of Zn-Mg Galvanized Steel Sheet “DYMAZING" Having Excellent Corrosion Resistance. Nippon. Steel Tech. Rep. 1999, 79, 63-67.

11. Nishimura, K.; Shindo, H.; Kato, K.; Morimoto, Y.; Funaki, S.O. Microstructure and corrosion behaviour of Zn-Mg-Al hotdip galvanized steel sheet. In Proceedings of the 4th International Conference on Zinc and Zinc Alloy Coated Steel Sheet (GALVATECH '98), Chiba, Japan, 20-23 September 1998; Masuko, N., Ed.; ISIJ: Tokyo, Japan, 1998; pp. 437-442.

12. Shindo, H.; Nishimura, K.; Kato, K. Anti-Corrosion in Atmospheric Exposure of Zn-Mg-Al Hot-Dip Galvanized Steel Sheet. In Proceedings of the 4th International Conference on Zinc and Zinc Alloy Coated Steel Sheet (GALVATECH '98), Chiba, Japan, 20-23 September 1998; Masuko, N., Ed.; ISIJ: Tokyo, Japan, 1998; pp. 433-4363.

13. Tsujimura, T.; Komatsu, A.; Andoh, A. Influence of Mg content in coating layer and coating structure on corrosion resistance of hot-dip Zn-Al-Mg-Si alloy coated steel shee. In Proceedings of the 5th International Conference on Zinc and Zinc Alloy Coated Steel Sheet (GALVATECH 2001), Brussels, Belgium, 26-28 June 2001; Lamberights, M., Ed.; Verl. Stahleisen: Düsseldorf, Germany, 2001; pp. 145-152, ISBN 3-514-00673-3.

14. Kittaka, T.; Andoh, A.; Komatsu, A.; Tsujimura, T.; Yamaki, N.; Watanabe, K. Hot-Dip Zn-Al-Mg Coated Steel Sheet Excellent in Corrosion Resistance and Surface Appearance and Process for the Production Thereof. U.S. Patent 6,235,410, 22 May 2001.

15. Tokuda, S.; Muto, I.; Sugawara, Y.; Takahashi, M.; Matsumoto, M.; Hara, N. Micro-electrochemical investigation on the role of Mg in sacrificial corrosion protection of 55mass\%Al-Zn-Mg coated steel. Corros. Sci. 2017, 129, 126-135. [CrossRef]

16. Vida, T.A.; Brito, C.; Lima, T.S.; Spinelli, J.E.; Cheung, N. Near-eutectic Zn-Mg alloys: Interrelations of solidification thermal parameters, microstructure length scale and tensile/corrosion properties. Curr. Appl. Phys. 2009, 51, 2355-2363. [CrossRef]

17. Krystýnová, M.; Doležal, P.; Fintová, S.; Zapletal, J.; Marada, T.; Wasserbauer, J. Characterization of Brittle Phase in Magnesium Based Materials Prepared by Powder Metallurgy. Key Eng. Mater. 2018, 784, 61-66. [CrossRef]

18. Vida, T.A.; Soares, T.; Septimio, R.S.; Brito, C.C.; Cheung, N.; Garcia, A. Effects of Macrosegregation and Microstructure on the Corrosion Resistance and Hardness of a Directionally Solidified Zn-5.0wt.\%Mg Alloy. Mater. Res. 2019, 22, 1-13. [CrossRef]

19. Pinc, J.; Čapek, J.; Kubásek, J.; Veřtát, P.; Hosová, K. Microstructure and mechanical properties of the potentially biodegradable ternary system Zn-Mg0.8-Ca0.2. Procedia Struct. Integr. 2019, 23, 21-26. [CrossRef]

20. De Bruycker, E.; Zermout, Z.; De Cooman, B.C. Zn-Al-Mg Coatings-Thermodynamic Analysis and Microstructure Related Properties. Mater. Sci. Forum 2007, 539-543, 1276-1281. [CrossRef] 
21. De Bruycker, E.; De Cooman, B.C.; De Meyer, M. Experimental study and microstructure simulation of Zn-Al-Mg coatings. Rev. Metall-CIT 2005, 102, 543-550. [CrossRef]

22. Akdeniz, V.M.; Wood, J.V. Microstructures and phase selection in rapidly solidified Zn-Mg alloys. J. Mater. Sci. 1996, 31, 545-550. [CrossRef]

23. Liu, H.Y.; Jones, H. Solidification Microstructure Selection and Characteristics in the Zinc-Based Zn-Mg System. Acta Metall. Mater. 1992, 40, 229-239. [CrossRef]

24. Prosek, T.; Nazarov, A.; Goodwin, F.; Šerák, J.; Thierry, D. Improving corrosion stability of Zn-Al-Mg by alloying for protection of car bodies. Surf. Coat. Technol. 2016, 306, 439-447. [CrossRef]

25. Farahany, S.; Tat, L.H.; Hamzah, E.; Bakhsheshi-Rad, H.R.; Cho, M.H. Microstructure development, phase reaction characteristics and properties of quaternary $\mathrm{Zn}-0.5 \mathrm{Al}-0.5 \mathrm{Mg}-\mathrm{xBi}$ hot dipped coating alloy under slow and fast cooling rates. Surf. Coat. Technol. 2017, 315, 112-122. [CrossRef]

26. Gondek, J.; Babinec, M.; Kusý, M. The corrosion performance of Zn-Al-Mg based alloys with tin addition in neutral salt spray environment. J. Achiev. Mater. Manuf. Eng. 2015, 70, 70-77.

27. Chen, J.; Chen, Z.; Yan, H.; Zhang, F.; Liao, K. Effects of Sn addition on microstructure and mechanical properties of Mg-Zn-Al alloys. J. Alloys Compd. 2008, 461, 209-215. [CrossRef]

28. Chen, L.; Yan, A.; Liu, H.; Li, X. Strength and fatigue fracture behaviour of Al-Zn-Mg-Cu-Zr(-Sn) alloys. Trans. Nonferrous Met. Soc. China 2013, 223, 2817-2825. [CrossRef]

29. Kim, B.; Do, J.S.; Lee, H.; Park, I. In situ fracture observation and fracture toughness analysis of squeeze cast AZ51-xSn magnesium alloys. Mater. Sci. Eng. A 2010, 527, 6745-6757. [CrossRef]

30. Turen, Y. Effect of Sn addition on microstructure, mechanical and casting properties of AZ91 alloy. Mater. Des. 2013, 49, 1009-1015. [CrossRef]

31. Wang, X.-Y.; Wang, Y.-F.; Wang, C.; Xu, S.; Rong, J.; Yang, Z.-Z.; Wang, J.-G.; Wang, H.-Y. A simultaneous improvement of both strength and ductility by $\mathrm{Sn}$ addition in as-extruded Mg-6Al-4Zn alloy. J. Mater. Sci. Technol. 2020, 49, 117-125. [CrossRef]

32. Ghosh, P.; Mezbahul-Islam, M.; Medraj, M. Critical assessment and thermodynamic modeling of Mg-Zn, Mg-Sn, Sn-Zn and Mg-Sn-Zn systems. Calphad 2012, 36, 28-43. [CrossRef]

33. Guangyin, Y.; Yangshan, S.; Wenjiang, D. Effects of Sn addition on the microstructure and mechanical properties of AZ91 magnesium alloy. Scripta Mater. 2001, 308, 34-38. [CrossRef]

34. Mezbahul-Islam, M.; Mostafa, A.O.; Medraj, M. Essential Magnesium Alloys Binary Phase Diagrams and Their Thermochemical Data. J. Mater. Hindawi 2014, 2014, 704283. [CrossRef]

35. Agarwal, G. (RWTH Aachen, Germany). Personal communication, 2014.

36. Kevorkijan, V.; Škapin, S.D. Preparation and Study of Mg2Sn-based Composites with Different Compositions. Mater. Tehnol. 2010, 44, 251-259.

37. Durmus, Y.E.; Montiel Guerrero, S.S.; Tempel, H.; Hausen, F.; Kungl, H.; Eichel, R.-A. Influence of Al alloying on the electrochemical behavior of $\mathrm{Zn}$ electrodes for $\mathrm{Zn}$-Air batteries with neutral sodium chloride electrolyte. Front. Chem. 2019, 7, 800. [CrossRef]

38. ISO. Metallic Materials_-Vickers Hardness Test; 6507-1:2018; International Organization for Standardization: Geneva, Switzerland, 2018.

39. Lutterotti, L.; Matthies, S.; Wenk, H.R. MAUD (Material Analysis Using Diffraction): A user friendly Java program for rietveld texture analysis and more. In Proceedings of the 12th International Conference on Textures of Materials (ICOTOM-12), Montreal, QC, Canada, 9-13 August 1999; Volume 1, p. 1599. Available online: http://hdl.handle.net/11572/57067 (accessed on 25 March 2021).

40. Schindelin, J.; Arganda-Carreras, I.; Frise, E.; Kaynig, V.; Longair, M.; Pietzsch, T.; Preibisch, S.; Rueden, C.; Saalfeld, S.; Schmid, B.; et al. Fiji: An open-source platform for biological-image analysis. Nat. Methods 2012, 9, 676-682. [CrossRef]

41. De Bruycker, E. Zn-Al-Mg coatings: Thermodynamic Analysis and Microstructure-Related Properties. Ph.D. Thesis, Ghent University, Ghent, Belgium, 2006.

42. Gogola, P.; Gabalcová, Z.; Suchánek, H.; Babinec, M.; Bonek, M.; Kusý, M. Quantitative x-ray diffraction analysis of Zn-Al based alloys. Arch. Metall. Mater. 2020, 65, 959-966. [CrossRef]

43. Prosek, T.; Persson, D.; Stoulil, J.; Thierry, D. Composition of corrosion products formed on $\mathrm{Zn}-\mathrm{Mg}, \mathrm{Zn}-\mathrm{Al}$ and $\mathrm{Zn}-\mathrm{Al}-\mathrm{Mg}$ coatings in model atmospheric conditions. Corros. Sci. 2014, 86, 231-238. [CrossRef]

44. Raghavan, V. Al-Mg-Zn (Aluminum-Magnesium-Zinc). JPED 2007, 28, 203-208. [CrossRef]

45. Meng, F.G.; Wang, J.; Liu, L.B.; Jin, Z.P. Thermodynamic modeling of the Mg-Sn-Zn ternary system. J. Alloys Compd. 2010, 508, 570-581. [CrossRef]

46. Larsson, L.E. Pre-precipitation and precipitation phenomena in the Al-Zn system. Acta Metall. 1967, 15, 35-45. [CrossRef]

47. Vlot, M.; Zuijderwijk, M.; Toose, M.; Elliot, L.; Bleeker, R.; Maalman, T. Hot dip ZnAlMg coatings: Microstructure and forming properties. In Proceedings of the 7th International Conference on Zinc and Zinc Alloy Coated Steel Sheet (Galvatech '07), Osaka, Japan, 19-21 November 2007; Tsuru, T., Ed.; ISIJ: Tokyo, Japan, 2007; pp. 574-579.

48. Kim, J.N.; Lee, C.S.; Jin, Y.S. Structure and Stoichiometry of MgxZny in Hot-Dipped Zn-Mg-Al Coating Layer on Interstitial-Free Steel. Met. Mater. Int. 2018, 24, 1090-1098. [CrossRef] 